\title{
SŁOWNIKI I TEKSTY PARALELNE W PRZEKŁADZIE TEKSTÓW PRAWNYCH
}

\author{
THE USE OF GLOSSARIES AND PARALLEL TEXTS \\ IN THE TRANSLATION OF LEGAL DOCUMENTS
}

\author{
ROBERT KOŚCIELNIAK
}

\begin{abstract}
AвstRact. The purpose of this article is to present the results of the research on the use of dictionaries and parallel texts in the translation process. Examples of collocations in legal texts were used in the research, and the resulting comparison shows the presence (or the absence) of the equivalents of the original units in the respective languages.
\end{abstract}

Keywords: glossary, parallel text, collocations, translation

Robert Kościelniak, Uniwersytet Szczeciński, Szczecin - Polska, koscielniakrobert@gmail.com ORCID ID: 0000-0002-8015-2201

W literaturze przedmiotu terminowi przekład poświęcono wiele prac (por. m.in. Pieńkos 1993; 2003; Lukszyn 1993; Kommisarow 1990), więc w tym miejscu należy tylko wspomnieć, że najczęściej jest on definiowany albo jako procedura lingwistyczna, albo jako tekst powstały w rezultacie jej zastosowania.

Do specyficznych typów przekładu należą tłumaczenia tekstów specjalistycznych, w tym tekstów napisanych językiem prawa. Tłumaczenia takie wymagają od tłumacza przygotowania merytorycznego [Lukszyn 1993: 367]. Jak słusznie zauważają Alicja Pisarska i Teresa Tomaszkiewicz, "podstawą każdego tłumaczenia jest najpierw zrozumienie, a później przekazanie w języku docelowym sensu oryginału" [Pisarska, Tomaszkiewicz 1996: 188]. Przekład tekstów specjalistycznych wymaga zatem od tłumacza nie tylko szerokich kompetencji przekładowych, tzn. znajomości języka oryginału i języka przekładu na najwyższym poziomie oraz znajomości technik translatorskich, ale także znajomości dziedziny, do której dany tekst się odnosi.

Na gruncie przekładoznawstwa rosyjskiego Anastazja Atabiekowa określa przekład prawny jako "proces nakierowany na przekład pojęć specyficznych kulturowo właściwych dla tekstów prawa" [Атабекова 2011]. W polskiej translatologii problemowi tego typu tłumaczeń wiele uwagi poświęcił Jerzy Pieńkos. Twierdzi on, że podstawowym problemem w przypadku tłumaczeń prawnych i prawniczych jest terminologia [Pieńkos 2003].

Terminy w tekstach prawa uznawane są za specyficzne i różniące się od terminów innych nauk tym, że osadzone są w systemie prawnym poszcze- 
gólnych krajów. Niezgodność terminologiczna ma swoje źródła w historii, zwyczajach i procedurach specyficznych dla odrębnych narodów. Zadaniem tłumacza przy przekładzie tego typu tekstów jest zatem nie tylko poszukiwanie odpowiednich ekwiwalentów na poziomie językowym, ale także na poziomie dwóch systemów prawnych.

Na jakość tłumaczenia rzutuje trafny wybór ekwiwalentów, dlatego pojęcie to jest jednym $z$ kluczowych, a dążenie do ich odnalezienia $w$ języku przekładu jednym z podstawowych zadań tłumacza.

Typową dla tłumaczeń tekstów prawnych i prawniczych jest klasyfikacja typów ekwiwalencji związana z modelem pragmatycznego ttumaczenia terminów prawnych, stworzonym przez Danutę Kierzkowską [2002]. Opracowany przez badaczkę model polega na określeniu rodzaju odbiorcy tekstu i powiązaniu z nim wyboru odpowiedniego typu ekwiwalencji i strategii przekładowej. Wyróżnia się trzech odbiorców: 1) odbiorca bliski, znający kulturę i rzeczywistość prawną języka źródłowego, dla którego właściwa będzie ekwiwalencja denotatywna; 2) odbiorca daleki, nieznający kultury i rzeczywistości prawnej języka źródłowego, dla którego stosowna będzie ekwiwalencja konotacyjna; 3) odbiorca samookreślony, narzucający tłumaczowi swoją własną terminologię, dla którego właściwa będzie ekwiwalencja pragmatyczna. Zdaniem Pieńkosa natomiast, w przypadku tekstów prawnych i prawniczych zastosowanie będą miały tzw. ekwiwalenty funkcjonalne, tj. takie, których funkcja w języku docelowym będzie taka sama lub podobna do funkcji, jaką pełnią w języku źródłowym.

W przekładzie tekstów prymarną rolę odgrywają słowniki. Jest to pierwsze źródło, do którego sięga tłumacz, przekładając tekst. Główną zaletą słowników, szczególnie tych w wersji elektronicznej, jest szybki dostęp do poszukiwanych ekwiwalentów.

Spośród dostępnych typów słowników najbardziej odpowiednie w procesie tłumaczenia byłyby, jak słusznie zauważa Weronika Szemińska, terminologiczne słowniki przekładowe. Charakteryzuje ona ten typ słownika w następujący sposób: „,słownik taki musi odpowiadać szczególnym potrzebom tłumacza, oferując ekwiwalenty obcojęzyczne terminów w języku źródłowym" [Szemińska 2009: 112-122]. Szemińska zauważa także fakt, iż wiele typologii leksykograficznych stawia go na równi z ogólnymi słownikami dwu- lub wielojęzycznymi, na dowód czego przytacza wyniki badań Marka Łukasika. Autor ten, analizując pojawiające się na rynku polskim w latach 1990-2006 specjalistyczne słowniki polsko-angielskie, żadnego z nich nie zakwalifikował do grupy słowników przekładowych [Łukasik 2009]. Podobne wnioski wysuwa także Martyna Klejnowska-Borowska, badająca słowniki specjalistyczne polsko-rosyjskie, które ukazały się na rynku w latach 19902012 [Klejnowska-Borowska 2014]. Zastosowanie słowników dwu- czy też wielojęzycznych w pracy tłumacza powinno być ograniczone do minimum. 
Słowniki takie często nie zawierają typowych połączeń wyrazowych, liczba odpowiedników nie zawsze jest dostateczna, a terminy bywają dobierane arbitralnie. Dla tłumacza słowniki te, wskazując odpowiednie pole leksykalne, powinny być wyłącznie punktem wyjścia do dalszych poszukiwań odpowiednich ekwiwalentów [Szemińska 2009: 112-122].

W procesie przekładu coraz częściej wykorzystuje się teksty paralelne. Zofia Krzysztoforska-Weisswassert definiuje teksty paralelne jako „teksty tego samego typu, na ten sam temat, które powstały w takiej samej sytuacji komunikacyjnej i służą za przykład w języku docelowym" [Krzysztoforska-Weisswasser]. Z kolei Aleksandra Matulewska zwraca uwagę na funkcjonowanie $\mathrm{w}$ teorii przekładu dwóch typów tekstów paralelnych: 1) teksty tego samego gatunku co tekst źródłowy, które funkcjonują w rzeczywistości języka docelowego; 2) teksty źródłowe wraz z ich tłumaczeniami na język docelowy [Matulewska 2010]. Matulewska zauważa przy tym, że podczas pracy z tekstami paralelnymi drugiego typu tłumacz, szczególnie początkujący, narażony jest na kopiowanie błędów, gdyż teksty te są często wątpliwej jakości.

Jedną z zalet tego typu tekstów jest możliwość zbadania i ustalenia znaczenia danego terminu na podstawie kontekstu, w jakim występuje on w tekście porównywanym. Analiza tych tekstów pozwala na uniknięcie błędów także na poziomie językowym, spowodowanych nieprawidłowym użyciem specyficznych konstrukcji składniowych właściwych różnym językom.

Analiza materiału. Badanie polegało na wyekscerpowaniu kolokacji ${ }^{1}$ z tekstu polskiego aktu normatywnego, tj. Ustawy z dnia 29 sierpnia $1997 \mathrm{r}$. o komornikach sądowych i egzekucji [UOKSIE]. Materiał poddany został zestawieniu z tekstami paralelnymi pierwszego typu, tzn. należącymi do tego samego gatunku i funkcjonującymi w rzeczywistości języka docelowego, w tym przypadku języka rosyjskiego, tj. Федеральный закон от 21.07.1997 N 118-Ф3 (ред. от 03.07.2016) „О судебных приставах” [ЗОСП] oraz Федеральный закон от 02.10.2007 N 229-Ф3 (ред. от 28.12.2016) „Об исполнительном производстве" [ЗОИП].

Spośród kolokacji polskich wybrane zostały 32 jednostki, które posiadają swój ekwiwalent funkcjonalny wyodrębniony $w$ tekstach rosyjskich ustaw. Następnie sprawdzono występowanie tych jednostek w trzech specjalistycznych słownikach bilingwalnych: Stowniku terminologii prawniczej polsko-rosyjskim [Zobek 2008], Stowniku prawniczym polsko-rosyjskim [Bar 1986], Polsko-rosyjskim słowniku par przekładowych [Chlebda 2014], jednym słowniku trzyjęzycznym: Polsko-rosyjsko-ukrainskim słowniku jezzyka oficjalno-urzędowego [Aleksiejenko 2002] oraz w jednym leksykonie: Leksykonie terminów prawniczych [Skoblenko 2011].

${ }^{1}$ Jako kolokację rozumiem stałe zidiomatyzowane zwroty lub połączenia konwencjonalne, które występują nieprzypadkowo i zgodnie z uzusem. 
Robert Kościelniak

\begin{tabular}{|c|c|c|c|c|c|c|c|c|c|}
\hline 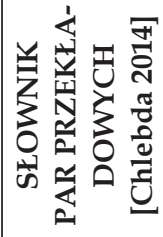 & $\times$ & $x$ & 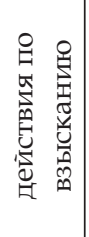 & 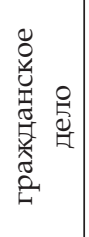 & $\times$ & $\times$ & $\times$ & 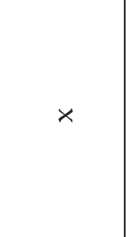 & $x$ \\
\hline 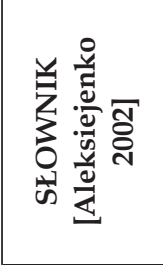 & 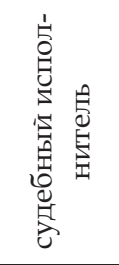 & 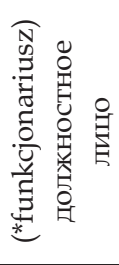 & $\times$ & 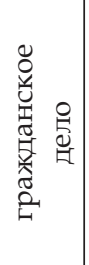 & $x$ & $\times$ & $\times$ & 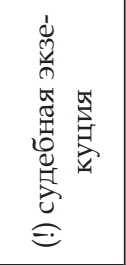 & 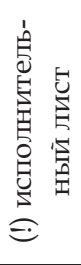 \\
\hline 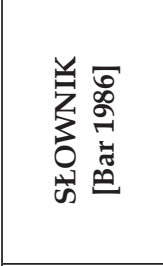 & 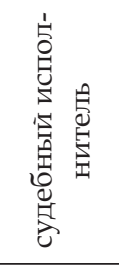 & 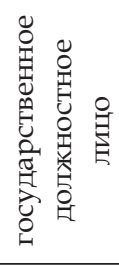 & 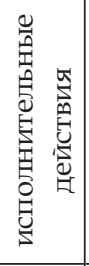 & $x$ & 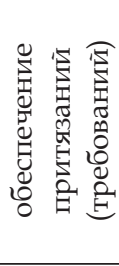 & 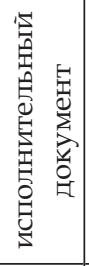 & 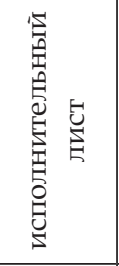 & 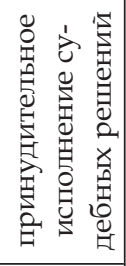 & 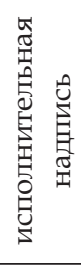 \\
\hline 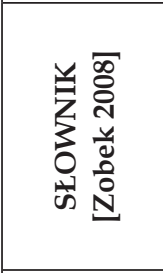 & 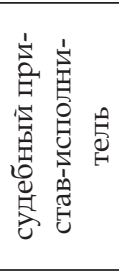 & 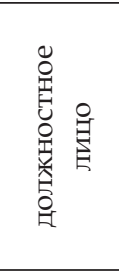 & 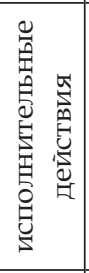 & 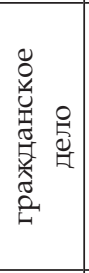 & $\ltimes$ & 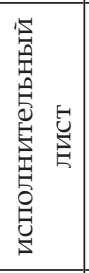 & 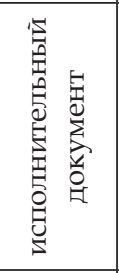 & 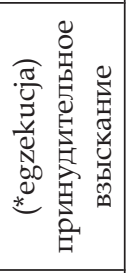 & 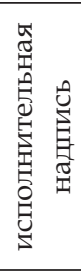 \\
\hline 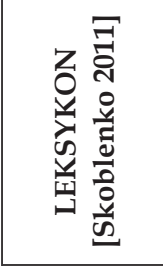 & 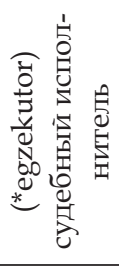 & $x$ & 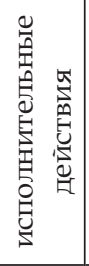 & $x$ & 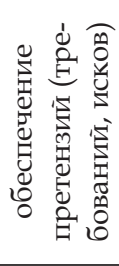 & $x$ & 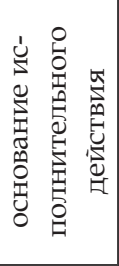 & 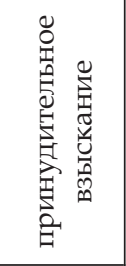 & $x$ \\
\hline 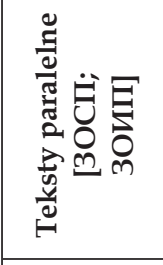 & 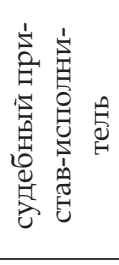 & 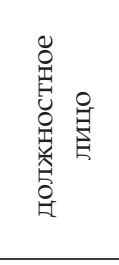 & 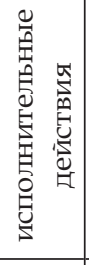 & 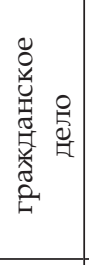 & 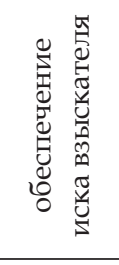 & 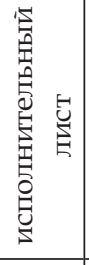 & 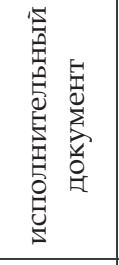 & 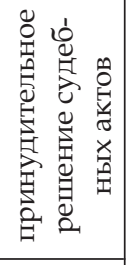 & 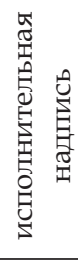 \\
\hline 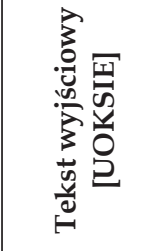 & 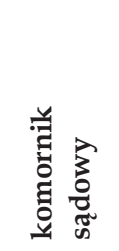 & 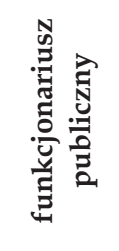 & 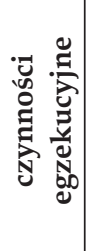 & 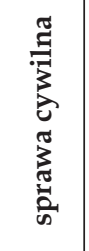 & 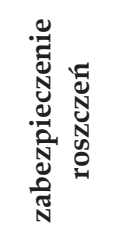 & 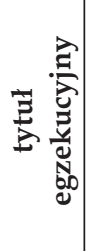 & 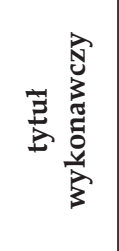 & 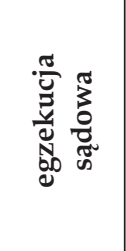 & 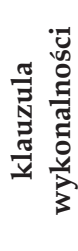 \\
\hline
\end{tabular}




\begin{tabular}{|c|c|c|c|c|c|c|c|c|}
\hline$x$ & $x$ & 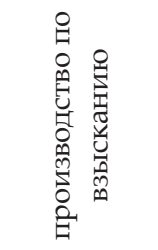 & $x$ & $x$ & $x$ & $x$ & 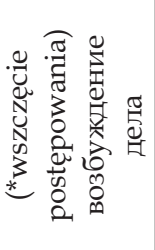 & $\times$ \\
\hline$x$ & 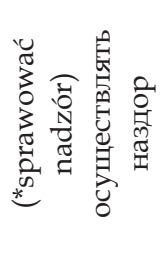 & 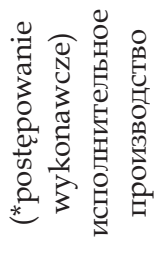 & 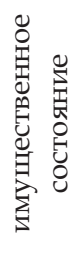 & $x$ & 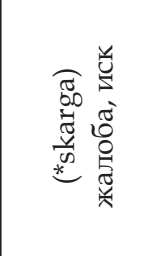 & 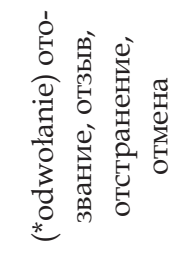 & 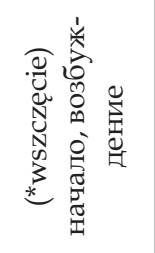 & 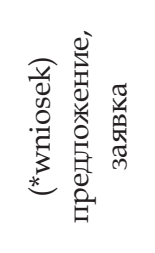 \\
\hline$x$ & 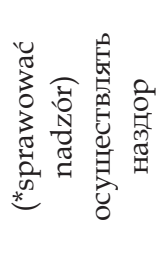 & 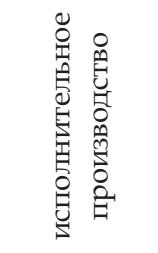 & 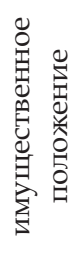 & 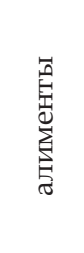 & 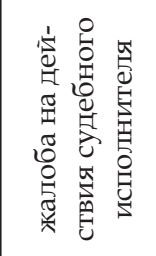 & 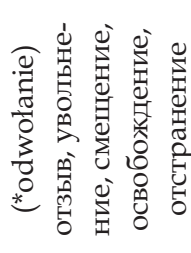 & 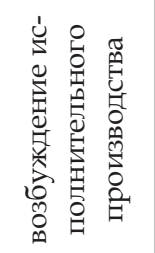 & 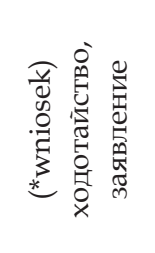 \\
\hline$x$ & 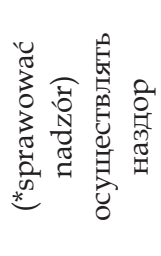 & 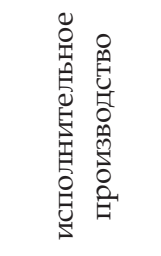 & $x$ & 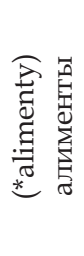 & 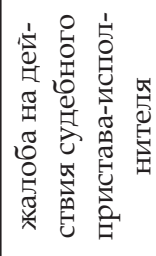 & 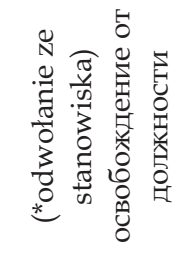 & 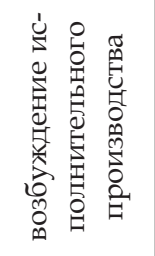 & 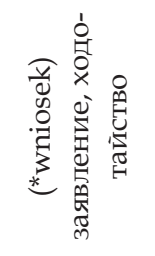 \\
\hline$\times$ & 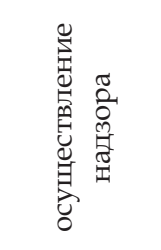 & 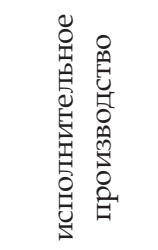 & $x$ & $x$ & 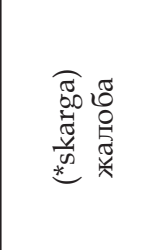 & 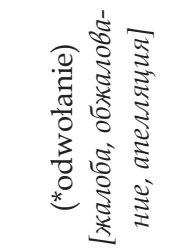 & $x$ & 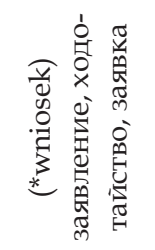 \\
\hline 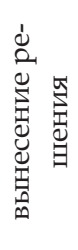 & 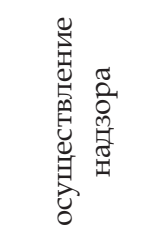 & 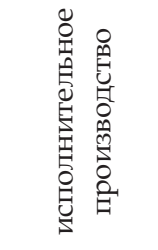 & 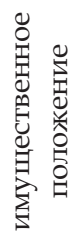 & 窇 & 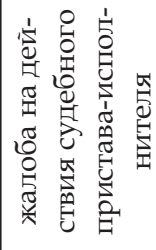 & 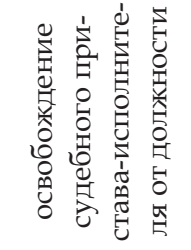 & 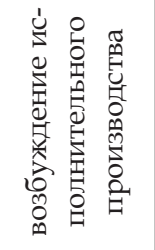 & 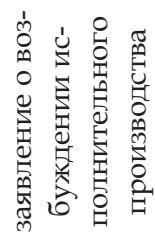 \\
\hline 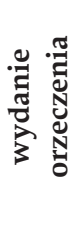 & 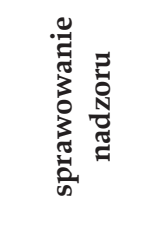 & 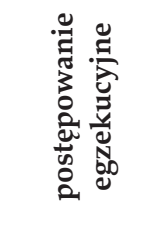 & 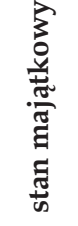 & 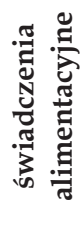 & 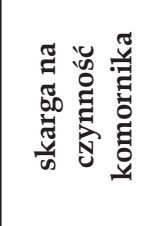 & 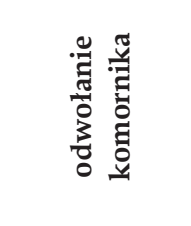 & 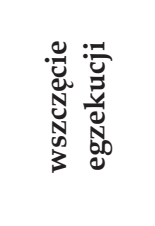 & 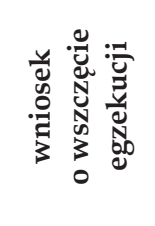 \\
\hline
\end{tabular}




\begin{tabular}{|c|c|c|c|c|c|c|}
\hline$\times$ & $x$ & $x$ & $\times$ & 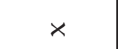 & 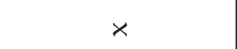 & $x$ \\
\hline$\times$ & $\times$ & 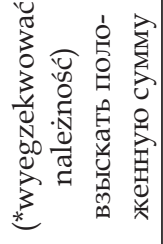 & $\times$ & $\times$ & 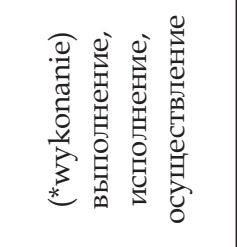 & $\times$ \\
\hline$\times$ & 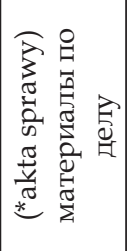 & $\times$ & 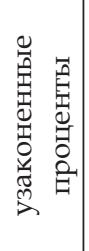 & 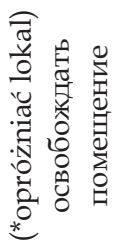 & 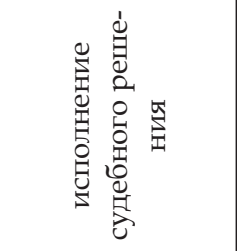 & 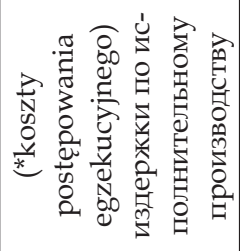 \\
\hline$x$ & 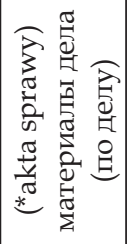 & 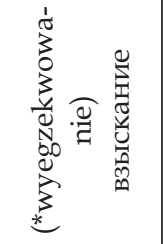 & 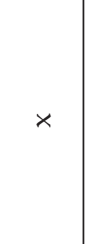 & $\times$ & 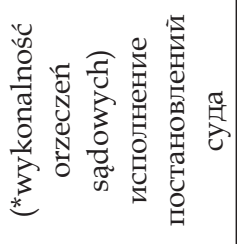 & $\times$ \\
\hline$x$ & $x$ & $x$ & $\times$ & $x$ & 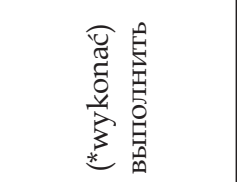 & $\times$ \\
\hline 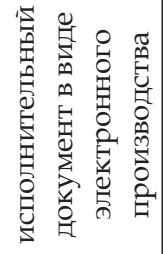 & 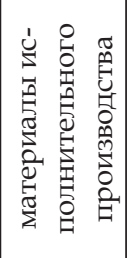 & 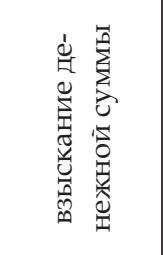 & 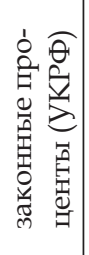 & 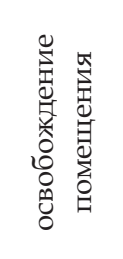 & 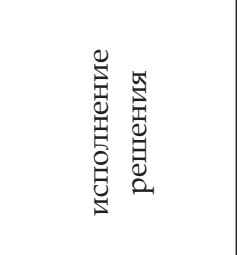 & 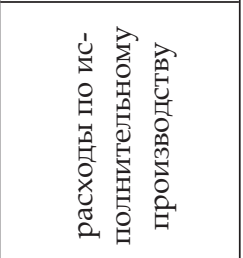 \\
\hline 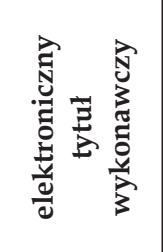 & 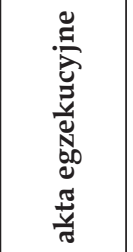 & 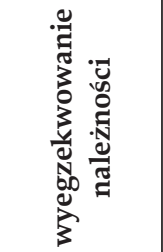 & 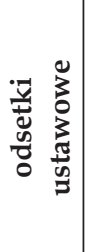 & 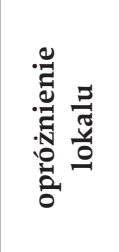 & 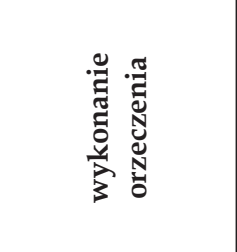 & 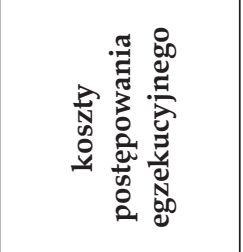 \\
\hline
\end{tabular}




\begin{tabular}{|c|c|c|c|c|c|c|}
\hline$\times$ & $x$ & 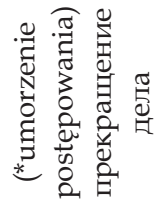 & $x$ & $\times$ & $\times$ & $\times$ \\
\hline 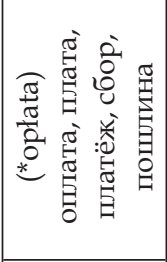 & $x$ & $\times$ & 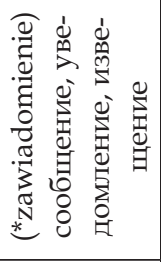 & 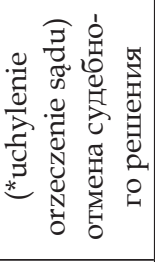 & $x$ & 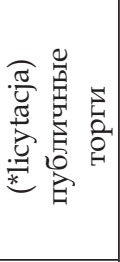 \\
\hline 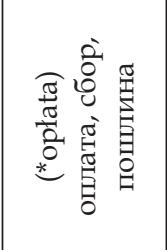 & 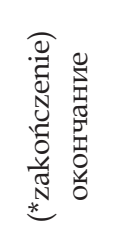 & 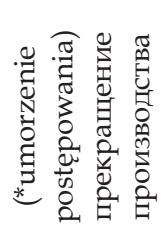 & 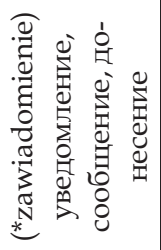 & 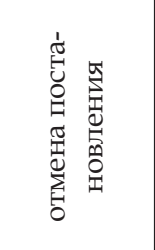 & $x$ & 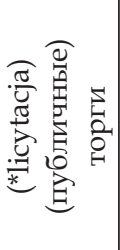 \\
\hline 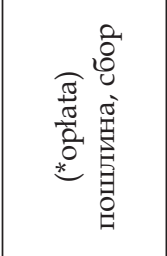 & 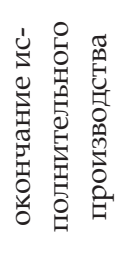 & 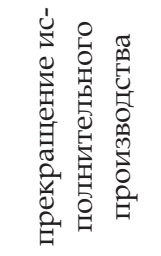 & 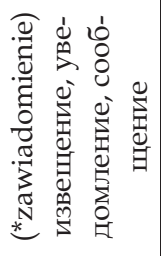 & $x$ & $x$ & 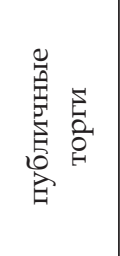 \\
\hline 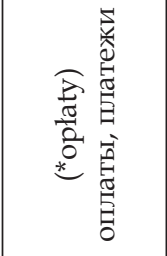 & $x$ & $x$ & $\times$ & $\times$ & $x$ & $\times$ \\
\hline 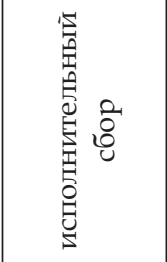 & 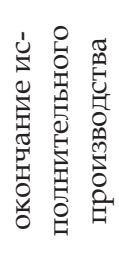 & 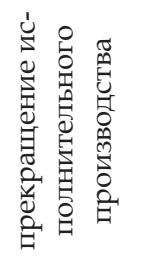 & 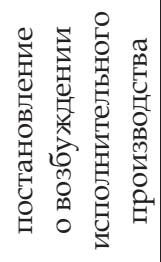 & 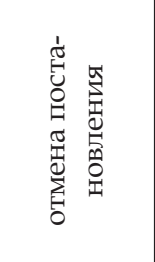 & 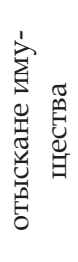 & 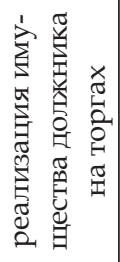 \\
\hline 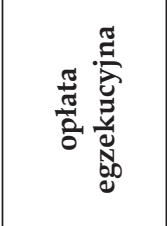 & 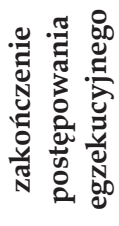 & 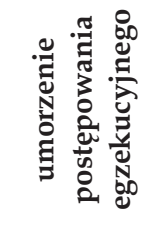 & 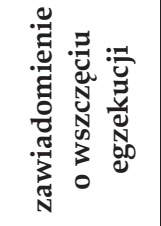 & 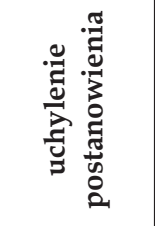 & 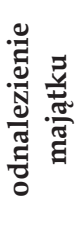 & 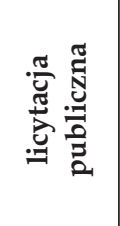 \\
\hline
\end{tabular}


Do celów niniejszej analizy przyjęto, zgodnie z klasyfikacją Kierzkowskiej, że odbiorcą przekładu będzie odbiorca bliski, w związku z czym materiał zbadany został pod kątem ekwiwalencji denotatywnej.

Jak wynika z powyższej tabeli, dla wszystkich 32 polskich kolokacji odpowiedni ekwiwalent ustalono tylko w tekstach paralelnych. Dodatkowo w tym przypadku kolokacje można było zbadać w kontekstach, co, jak zostało wspomniane wcześniej, jest niewątpliwą zaletą tekstów paralelnych.

Znajomość obcej rzeczywistości prawnej, będąca jedną z podstawowych cech dobrego tłumacza oraz dobrego jakościowo tłumaczenia, okazuje się nieodzowna w wypadku kolokacji komornik sq̨dowy, oznaczającej osobę, która zgodnie z Ustawą wykonuje orzeczenia sądu. W rosyjskiej przestrzeni prawnej istnieją dwa pojęcia na określenie osób wykonujących zawód komornika w zależności od realizowanych przez nie zadań: судебный пристав, który zajmuje się zabezpieczeniem osób i spraw związanych z działalnością sądu oraz судебныu пристав-исполнитель, który zajmuje się wykonywaniem orzeczeń sądowych. Tylko znajomość rosyjskiego prawa pozwala w tym przypadku znaleźć prawidłowy ekwiwalent poprzez zbadanie analogii wykonywanych zadań. Zatem zgodnie z polską i rosyjską rzeczywistością prawną prawidłowym ekwiwalentem w tym przypadku będzie судебный пристав-исполнитель.

$\mathrm{Z}$ zasady jednostkę hasłową tworzy pojedynczy leksem, dla którego w wielu przypadkach słowniki podają kilka możliwych ekwiwalentów. Słowniki, co prawda, notują w rozwinięciu artykułu hasłowego typowe kolokacje z danym leksemem, jednak, jak pokazała analiza, ich dobór bywa dokonany pobieżnie i brakuje niektórych specyficznych zwrotów. Na przykład, pomimo umieszczenia odrębnego hasła POSTĘPOWANIE EGZEKUCYJNE w Leksykonie terminów prawniczych [Skoblenko 2011], autor nie podaje takich typowych dla postępowania egzekucyjnego zwrotów jak: skarga na czynność komornika, wszczęcie egzekucji, akta egzekucyjne, koszty postępowania egzekucyjnego czy opłata egzekucyjna. Podobne braki zauważa się także w innych słownikach.

Z ilością podanych ekwiwalentów przy haśle wiąże się problem wyboru tego, który w języku przekładu utworzy prawidłową kolokację, np. żaden $\mathrm{z}$ analizowanych słowników nie zawiera zwrotu opłata egzekucyjna, natomiast w czterech występuje hasło opłata, dla którego podaje się kilka możliwych ekwiwalentów takich jak: оплата, платеж, пошлина, сбор, плата. Dopiero wykorzystanie tekstów paralelnych pozwoliło na prawidłowe określenie ekwiwalentu opłaty egzekucyjnej, którym jest połączenie wyrazowe ucno нительный сбор.

Poważnym problemem są także błędy przy określaniu ekwiwalentów w słownikach. Polsko-rosyjsko-ukraiński słownik języka oficjalno-urzędowego Michaiła Aleksiejenki [Aleksiejenko 2002] dla hasła klauzula wykonalności podaje ekwiwalent исполнительный лист. Zgodnie z rosyjską ustawą zwrot ten 
oznacza typ dokumentu uprawniającego do wszczęcia postępowania egzekucyjnego, czyli jest odpowiednikiem polskiego terminu tytuł wykonawczy, natomiast исполнительная надиись to potwierdzenie przez notariusza, że dokument może zostać skierowany do egzekucji, a więc przez analogię do polskich przepisów - klauzula wykonalności. Błąd polega na nieprawidłowym określeniu kontekstu, w jakim występują dane kolokacje, i, prawdopodobnie, braku porównania dwóch systemów prawnych. Podobny błąd w tłumaczeniu wspomnianego terminu pojawił się w Słowniku prawniczym polsko-rosyjskim wydawnictwa Polskiej Akademii Nauk [Bar 1986]. Tam autor błędnie ustalił ekwiwalent przekładowy w obrębie pary: tytuł wykonawczy - tytuł egzekисуjny, wskazując, iż ten pierwszy to исполнительный лист, a drugi - исполнительный документ. Analiza kontekstu, w jakim są one użyte w rosyjskich tekstach paralelnych, oraz porównanie jej wyników z polską rzeczywistością prawną pozwoliłoby na uniknięcie błędu.

Analiza tak niewielkiego fragmentu języka prawnego poprzez zestawienie poszczególnych kolokacji występujących w różnych słownikach z tekstami paralelnymi pokazuje słuszność wykorzystywania tych drugich w procesie przekładu. Do zalet takiej metody przekładu tekstów zaliczyć można przede wszystkim fakt, że ekwiwalenty wyszukiwane są w tekstach należących do kultury prawnej języka oryginału, znajdują się w swoim naturalnym językowym środowisku. Tłumacz, mając przed sobą paralelny tekst ustawy, nie musi zastanawiać się nad kontekstem użycia danego wyrażenia. Tutaj tłumacz szuka gotowego wyrażenia w kontekście, a nie odwrotnie, jak w przypadku wyszukiwania ekwiwalentów w słownikach.

Ponadto, jak widać w zestawieniu, słowniki nie zawsze notują całą kolokację występującą $\mathrm{w}$ języku prawnym, która jest przecież zwrotem stałym. Zadaniem tłumacza $\mathrm{w}$ tym przypadku jest odnajdywanie kilku osobnych haseł i zestawienie ich w jeden zwrot. Metoda taka, w sytuacji, kiedy hasła mają po kilka, a nawet kilkanaście ekwiwalentów, znacznie utrudnia zadanie i może doprowadzić do użycia błędnego połączenia, co z kolei może mieć swoje konsekwencje w błędnym interpretowaniu terminu lub całego przepisu prawnego.

Teksty paralelne wypełniają także lukę występującą na rynku wydawniczym w dostępie do polsko-rosyjskich słowników specjalistycznych, w tym przekładowych. Brakuje słowników prawnych ukierunkowanych na poszczególne gałęzie prawa. Te aktualnie dostępne zawierają leksykę ogólnoprawną, często przestarzałą, np. termin судебный исполнитель nie funkcjonuje w prawie rosyjskim od 1997 r., a nadal jest notowany w słownikach.

Fakt, że teksty paralelne w procesie przekładu odgrywają ogromną rolę, jest nie do podważenia. Wyszukiwanie w tych tekstach ekwiwalentów i porównywanie ich $\mathrm{z}$ tekstami języka oryginału jest czasochłonne, jednak często 
jednokrotne - raz odnaleziony ekwiwalent przekładowy, ze względu na dyrektywność tekstów prawa, może być użyty w kolejnych tłumaczeniach tego typu tekstów. Należy zatem zachęcać tłumaczy do pracy z tekstami paralelnymi, gdyż na pewno wpływa to na poprawę jakości tłumaczenia, a w konsekwencji na umocnienie pozycji tłumacza na rynku za sprawą profesjonalnych przekładów.

\section{Bibliografia}

Jopek-Bosiacka A. 2009. Przekład prawny i sądowy, Warszawa: Wydawnictwo Naukowe PWN.

Kierzkowska D. 2002. Ttumaczenie prawnicze, Warszawa: Translegis.

Klejnowska-Borowska M. 2014. Analiza wielojęzycznych stowników specjalistycznych $z$ językiem polskim $i$ rosyjskim wydanych w latach 1990-2012, źródło elektroniczne: http://s3.amazonaws.com/academia.edu.documents/35587635/SN_17_Marek_ Lukasik_Beata_Mikolajewska_red._Jezyki_specjalistyczne_wczoraj_dzis_i_jutro. pdf?AWSAccessKeyId=AKIAIWOWYYGZ2Y53UL3A\&Expires=1495911335\&Signa ture $=z$ V65SM3aKke0cEKSIA6r1Q7xD1I\%3D\&response-content-disposition=inli ne\%3B\%20filename\%3D Jezyki_specjalistyczne_wczoraj_dzis_i_ju.pdf\#page=128 (dostęp: 27.05.2017).

Krzysztoforska-Weisswasser Z. 1995. Wykorzystanie tekstów paralelnych przy ttumaczeniu wyroków w procesie cywilnym, źródło elektroniczne: http://translegis.com.pl/ ll_archi wum/ LL_2_6.pdf (dostęp: 27.05.2017).

Kubacki A. 2009. Relacje interlingwalnemiędzy niemieckimi derywatamiz-ung aichodpowiednikami w języku polskim, źródło elektroniczne: http:/ / inveling.amu.edu. pl/pdf/Kubacki_ Relacje_17.pdf (dostęp: 27.05.2017).

Lukszyn J. (red.) 1993. Tezaurus terminologii translatorycznej, Warszawa: Wydawnictwo Naukowe PWN.

Matulewska A. 2010. Teksty paralelne a ustalanie konotatów i denotatów na potrzeby przektadu polsko-angielskiego, źródło elektroniczne: https:/ / repozytorium.amu.edu.pl/bitstream/ 10593/14318/1/CL_03_2010_05\%20Aleksandra\%20MATULEWSKA\%20(Polska), \%20 Teksty\%20paralelne\%20a\%20ustalenie\%20konotatów\%20i\%20denotatów\%20na \%20 potrzeby\%20przekładu\%20polskoangielskiego.pdf (dostęp: 27.05.2017).

Pieńkos J. 1993. Przekład i ttumacz we wspótczesnym świecie. Aspekty lingwistyczne i pozalingwistyczne, Warszawa: Wydawnictwo Naukowe PWN.

Pieńkos J. 2003. Podstawy przekładoznawstwa. Od teorii do praktyki, Kraków: Kantor Wydawniczy Zakamycze.

Pisarska A., Tomaszkiewicz T. 1996. Wspótczesne tendencje przekładoznawcze, Poznań: Wydawnictwo Naukowe UAM.

Szemińska W. 2009. Terminologiczny stownik przekładowy: w poszukiwaniu narzędzia doskonaŁego, [w:] M. Łukasik (red.), Na drodze wiedzy specjalistycznej, Warszawa: Katedra Języków Specjalistycznych Uniwersytetu Warszawskiego, s. 112-122.

Wróblewski B. 1948. Język prawny i prawniczy, Kraków: Polska Akademia Umiejętności. 
Атабекова А. А. 2011. Юридический перевод: интерпретация, адаптация, медиация, źródło elektroniczne: http://globaljournals.ru/assets/files/journals/science-andbusiness /6/ sb-6-011.pdf\#page=85 (dostęp: 27.05.2017).

Комиссаров В. Н. 1990. Теория перевода (лингвистические аспекты), Москва: Высшая школа.

\section{Słowniki i leksykony}

Aleksiejenko M. 2002. Polsko-rosyjsko-ukraiński stownik języka oficjalno-urzędowego, Moskwa: Azbukownik.

Bar L. (red.). 1986. Słownik prawniczy polsko-rosyjski, Wrocław-Warszawa-Kraków-GdańskŁódź: Wydawnictwo Polskiej Akademii Nauk.

Chlebda W. (red.). 2014. Polsko-rosyjski stownik par przektadowych. Tom zbiorczy idiomatykonu polsko-rosyjskiego (z. 1-5), Opole: Wydawnictwo Uniwersytetu Opolskiego.

Skoblenko A. 2011. Leksykon terminów prawniczych, Warszawa: C.H. Beck.

Zobek T. 2008. Stownik terminologii prawniczej polsko-rosyjski, Warszawa: C.H. Beck.

\section{Akty normatywne}

UOKSIE - Ustawa z dnia 29 sierpnia 1997 r. o komornikach sądowych i egzekucji (stan prawny na 8.09.2016).

ЗОСП - Федеральный закон от 21.07.1997 N 118-Ф3 (ред. от 3.07.2016) „О судебных приставах".

ЗОИП - Федеральный закон от 2.10.2007 N 229-Ф3 (ред. от 28.12.2016) „Об исполнительном производстве". 
